Szent János Kórház és Észak-budai Egyesített Kórházak, Budapest, Szemészeti Osztály, II. Belgyógyászat-Diabetológia, az SE ÁOK oktató- és gyakorlóosztálya, ${ }^{2}$ Miskolci Egyetem, Egészségügyi Kar, Elméleti Egészségtudományi Intézet, Miskolc ${ }^{3}$

\title{
A diabeteses maculopathia vizsgálata optikai koherencia tomográfia segítségével
}

\author{
Bodrogi Petra dr., ${ }^{(1)}$ Gombos Katalin dr., ${ }^{(1)}$ Winkler Gábor dr. ${ }^{(2,3)}$
}

\begin{abstract}
Összefoglalás
Az optikai koherencia tomográfia (OCT) pontos, nem megterhelö, az aktuális állapot rögzitésére kiválóan alkalmas kiegészitö eljárás a cukorbetegség szemészeti szövödményeinek vizsgálatára és azok követésére. Alkalmazásával - a módszertani ajánlásokban szereplö, rendszeres időközönként végzett szemészeti ellenörzés esetén - a diabetes szemészeti szövődményei hatékonyabban felismerhetök és kezelhetök, még mielött jelentös látásromlást okoznának. Számos tanulmány kimutatta, hogy a retina vastagságának növekedésével romlik a centrális látás, valamint hogy e vastagságváltozás korai kimutatására az OCT kiválóan alkalmas: a maculavastagság korai növekedését térfogatának növekedése elöbb jelezheti, mint a foveolaris vastagság növekedése. Intézetünkben 2013-ban bevezettük a gondozott cukorbetegek retinaambulancián történö, OCT-vel is kiegészitett vizsgálatát. Retrospektiv feldolgozásunkban a 2016 végéig vizsgált 195 személy adatait elemeztük. Közülük 60 személy 24 hónapot meghaladó, három vizsgálatot magában foglaló adatai is rendelkezésre állnak. Adataink megerösitik az OCT-vizsgálat jelentöségét cukorbetegek szemészeti ellenörzésében. Javasoljuk a macula kiemelt vizsgálatát, s a foveolaris vastagság értékelése mellett a macula térfogatának figyelembevételét is.
\end{abstract}

Kulcsszavak: diabetes mellitus, optikai koherencia tomográfia, maculatérfogat, foveolaris vastagság

\section{Examination of diabetic maculopathy using optical coherence tomography}

Summary: Optical coherence tomography (OCT) is an accurate, non-burdensome, suitable additional testing procedure for recording current state and following ocular complications of diabetes. By this tool ophthalmic complications of diabetes can be managed more effectively and even detected before they cause substantial loss of vision. Studies have shown that the increase of retinal thickness cause deterioration of central vision and that OCT is a suitable tool to detect this change in retina thickness early. It has also been verified before, that changes in macular volume are more important in indicating diabetic macula edema than the increase of central foveolar thickness. In 2013 an outpatient retina clinic was organized in our institute, where among others the yearly examination including OCT of the cared diabetic patients is also performed. In the present retrospective analysis data of 195 patients examined till the end of 2016 are evaluated, 60 of which could be followed already for at least 24 months. Our data confirm the importance of OCT in the ophthalmological care of diabetic patients. We raise awareness to fix the foveolar thickness and macular volume at each control.

Keywords: diabetes mellitus, optical coherence tomography, macular volume, foveolar thickness

Röviditések

ВОт: bázisinzulinnal kiegészített orális kezelés (basal insulin supplemented oral therapy); CSMO: klinikailag szignifikáns maculaoedema (clinical significant macula oedema); DM: diabetes mellitus; DME: diabeteses maculaoedema; DRP: diabeteses retinopathia; OCT: optikai koherencia tomográfia (optical coherence tomography); SD: átlagos szórás (standard deviation); T1-, T2DM: 1-es, 2-es típusú diabetes mellitus; VEGF: vascularis endothelialis növekedési faktor (vascular endothelial growth factor) 


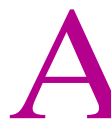
diabetes a leggyakoribb olyan belgyógyászati betegség, amely látáskárosodáshoz vezet. A legtöbb szemészeti tünet a microangiopathia következménye, bár a diabetes egyéb eltéréseket is okozhat, amelyek rontják a beteg életminőségét (pl. korai szürkehályog-kép- ződés, szemhéjszéli és szemfelszíni gyulladások stb.).

Az optikai koherencia tomográfia (OCT) olyan, az orvostudomány számos területén alkalmazott, ${ }^{1,2}$ nem invazív, nagy felbontóképességű képalkotó eljárás, amely diódalézer segítségével előállított, 820
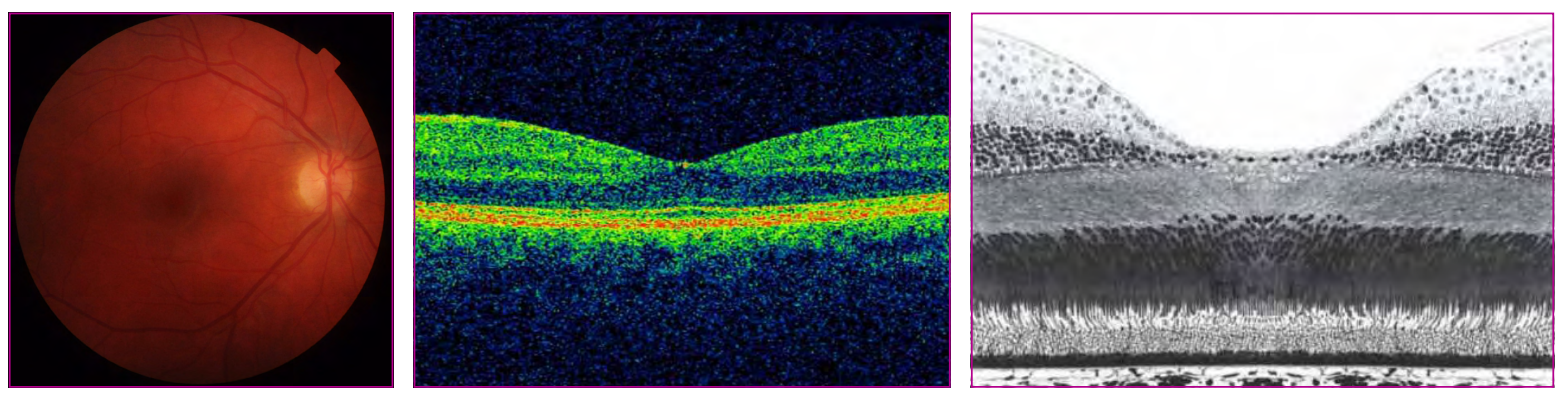

1. ábra. Ép szem szemfenéki (bal oldali képrészlet) és OCT (középső részlet) kép. A jobb oldali ábrarészleten a foveáról készült elektronmikroszkópos felvétel. Látható, hogy az OCT-felvétel szinte szövettani pontosságú Az éles látásban kitüntetett szerepe van a macula luteának (sárgafolt). Ennek szövettani képén látható, hogy a retina 10 rétege itt speciális szerkezetü. A kb. 1,5 mm átmérőjü, jellegzetes behúzottságot mutató centrális terület neve fovea, amelynek közepében található a foveola, ahol a receptorsejtek a legnagyobb koncentrációban találhatók és kizárólag csapok alkotják.

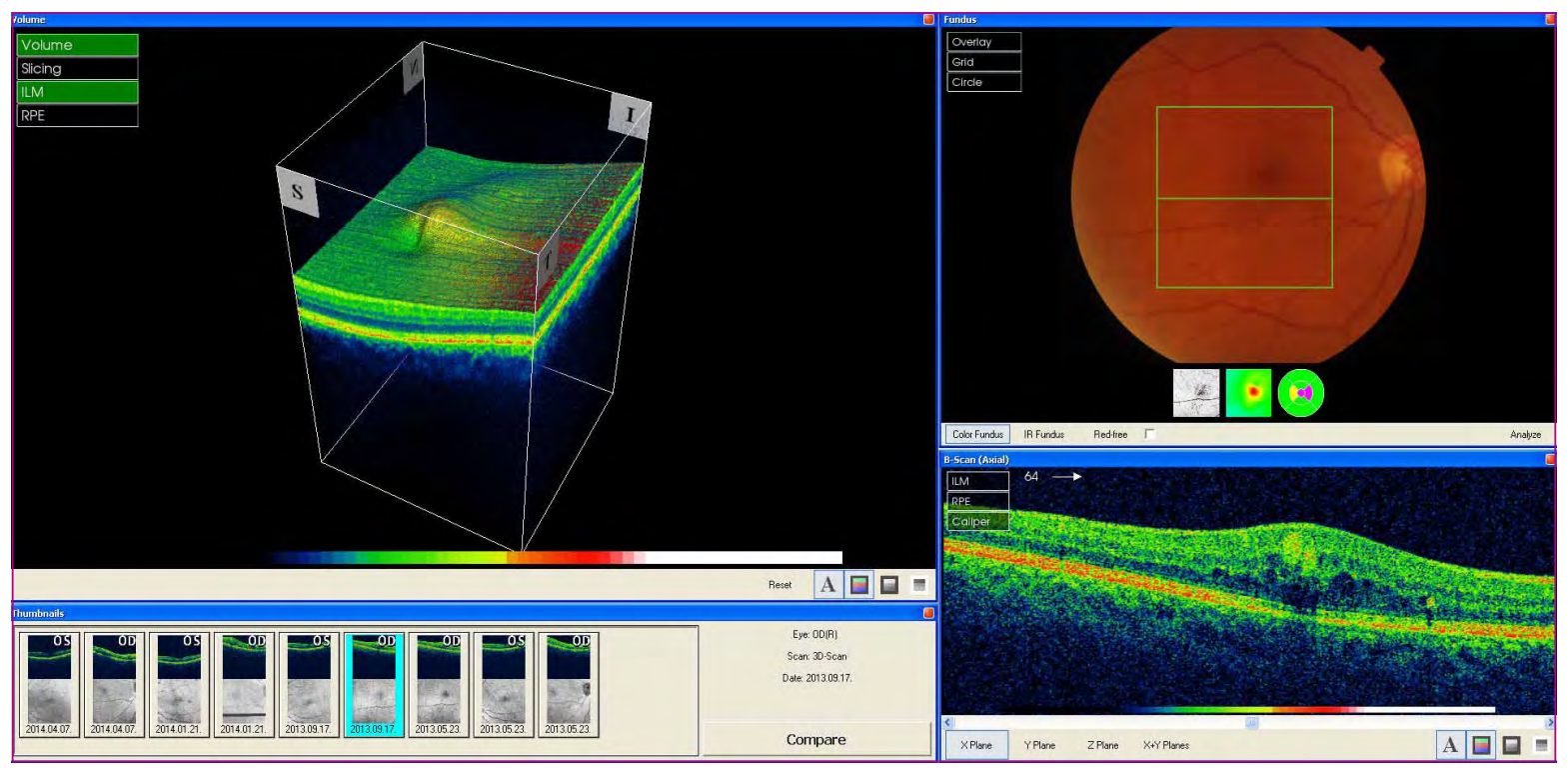

2. ábra. Diabeteses maculaoedema OCT-képe. A jobb oldali, felső, szemfenéki képen az elváltozás alig ismerhető fel

A háromdimenziós feldolgozású bal oldali képen a fovea területén keletkezett elődomborodás látható, amely fokális oedemának felel meg, kemény exsudatummal. Ennek keresztmetszeti képét látjuk a jobb alsó sarokban. Megfigyelhetö, hogy az oedema mely retinarétegekben helyezkedik el 
nm-es koherens fénynyalábbal pásztázza a vizsgált képleteket. ${ }^{3,4}$ A visszaverődő fénynyaláb intenzitása és az elnyelődés mértéke az adott szöveti struktúra optikai denzitásától függ, ezt a készülék a Doppler-elv alapján értékeli. Ennek alapján közel szövettani finomságú képet állít elő, amelyen a színek ún. hamis színkódolt skálán megfeleltetett optikai denzitást jelölnek.

A szemészetben alkalmazott OCT-vizsgálat elsősorban a szemfenéki képleteket, azon belül is a maculát, illetve - valamivel ritkábban - a szem elülső részének feltérképezését végzi. Az eljárás nem jár nagyobb megterheléssel, mint egy szemfenékvizsgálat, tiszta törőközegek esetén a pupillatágítás sem feltétlenül szükséges. A készülékek standard adatbázissal, valamint interaktív kép- és adatelemző szoftverrel rendelkeznek. Az eljárás kvalitatív és kvantitatív mérésekre egyaránt alkalmas, adott kórfolyamat progresszióját és a kezelés hatékonyságát is objektív módon méri. További előnye, hogy a vizsgálat reprodukálható. A 3. és 4. generációs gépek több mint 40000 felvételre képesek másodpercenként, a retina közel sejtszinten ábrázolódik, a felbontásuk 2-3 mikron. Az eljárás korlátai jelenthetik a hátrányait: a beteg vagy a vizsgáló mozgásából adódó műtermék (artefactum), képhibák, fixálási, szegmentációs hibák, törőközegi homályok, illetve a pupilla túl kicsi mérete. Nem ad információt a szövetek perfúziójáról, esetleges ischaemiájáról, ezekre továbbra is a fluorescein angiographia marad alkalmas vizsgálóeljárás. A vastagságbeli eltérések csak mérsékelt összefüggést mutatnak a látóélesség változásaival, így bár a vizsgálat a diabeteses maculaoedema (DME) értékelésében fontos szerepet játszik, a funkcionális eltérést nem tudja előre jelezni. ${ }^{4}$

2013 nyarán kezdődött szoros együttműködés kórházunk szemészeti és diabetológiai osztálya és szakrendelései között. A kezdeti szakaszban, a 2014 márciusáig bevont betegek adatainak első elemzéséről előadásban számoltunk be a Magyar Diabetes Társaság kongresszusán. ${ }^{5}$ A jelen munkában a 2016 szeptemberéig, OCT-vel is vizsgált 195 diabeteses személy adatait elemezzük, külön kitérve a 60 , legalább három komplex szemészeti állapotfelvételen megjelent cukorbeteg szemfenéki képe és anyagcsere-állapota közötti kapcsolatra.

Osztályunkon Topcon 2000 típusú készüléket használunk, adatelemzéshez $6 \times 6$ mm-es 3D-maculascant alkalmazunk (1. és 2. ábra).

\section{Betegek, módszerek}

Intézetünkben 2013-ban kezdeményeztük retinaambulancia működését, amely a diabetológiai szakrendeléssel szorosan együttműködve cukorbetegek részletes, OCT-vizsgálatot is magában foglaló ellenőrzését is végzi. A vizsgálat képi archiválása pendrive-on is megtörténik, amelyet a beteg a következő ellenőrzéskor magával visz - addig egyéb dokumentációjával együtt a diabetológiai szakrendelés tárolja -, így minden esetben közvetlen összehasonlításra nyílik lehetőség. A kézirat lezárásig 195 cukorbeteg vizsgálatára került sor az évenkénti ellenőrzés keretében, közülük 60 gondozott személy legalább kétéves, három vizsgálatot magukban foglaló ellenőrzési adatai is rendelkezésre állnak. Betegeink életkori jellemzőit, diabetestípus és ismert diabetestartam szerinti megoszlását az 1. táblázatban foglaltuk össze.

Retrospektív feldolgozásunkban rögzítettük a visust, a szemmozgásokkal kapcsolatos adatokat, a tágított pupilla mellett vizsgált szemfenéki jellemzőket, az OCT-felvételek adatait. Ez utóbbiak között elemeztük az átlagos foveavastagság ( $6 \times 6$ mm-es, négyzet alakú területen meghatározva), a centrális vastagság (=foveola) és a vizsgált teljes maculatérfogat értékeit. ${ }^{5,6}$ Rögzítettük a maculában ischaemiára vagy oedemára utaló jelek meglétét vagy hiányát, valamint - ha igazolható volt - a klinikailag szignifikáns macula-

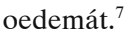

Felmérésünk első szakaszában arra kerestünk választ, hogy hogyan alakul diabeteses betegeink maculavastagsága a standard értékekhez képest; az OCT-kép mennyire korrelál a réslámpás vizsgálattal; a retina vastagsága összefügg-e a látásélesség romlásával. A második, követési szakaszban kiegészítettük ezt a maculavastagság változásának adataival és annak elemzésével, hogy hogyan alakult az a diabetes kórismézésétől eltelt idő és a $\mathrm{HbA}_{1 c}$-értékek függvényében. Vizsgáltuk az észlelt elváltozások folytán bevezetett kezelés fenti jellemzőkkel értékelhető eredményességét is.

\section{1. táblázat. A retrospektív adatfeldolgozásba vont betegek föbb klinikai jellemzői}

\begin{tabular}{|c|c|}
\hline Életkor (átlag $\pm S D$, szélsőértékek) & $59,5 \pm 13,7(22-85)$ év \\
\hline Nemi megoszlás (férfi/nő) & $98 / 97$ \\
\hline Típus szerinti megoszlás & $\begin{array}{c}\text { 1-es típus: } 55 \\
\text { 2-es típus: } 132 \\
\text { egyéb: } 8\end{array}$ \\
\hline Újonnan (<1 év) felismert & $53(27,17 \%)$ \\
\hline $1-10$ éve felismert & $61(31,28 \%)$ \\
\hline $10-20$ éve felismert & $60(30,76 \%)$ \\
\hline$>20$ éve felismert & $21(10,76 \%)$ \\
\hline
\end{tabular}




\section{Eredmények}

A 195 vizsgált személy átlagos foveaértékeit a 2. táblázatban foglaltuk össze. Adataikat - a hamis színkódolt képek figyelembevételével ${ }^{3}$ - az OCT készülék standard adatbázisához hasonlítottuk. Az első vizsgálat alkalmával felvett látásélesség az alábbi volt (390 szem, a megadott számok és százalékértékek a szemekre vonatkoznak). Teljes visus $(1,0)$ : 343 (87,9\%), 0,5-0,9 között 36 (9,2\%), 0,1-0,4 között 6 (1,5\%), <0,1 (nincs táblavisus): 5 (1,28\%).

A 195-ből 62 beteg $(31,8 \%)$ esetében volt az első szemészeti vizsgálat idején mért $\mathrm{HbA}_{1 \mathrm{c}}$-érték $>8,0 \%$ (átlag $8,76 \pm 0,7 \%$ ). A magasabb kezdeti $\mathrm{HbA}_{1 \mathrm{c}}$-értékekkel rendelkező személyek átlagos macula (fovea)-vastagsága (jobb szem: $268,55 \pm 19,27$, bal szem: $268,54 \pm 35,78 \mu \mathrm{m}$ ) érdemben nem különbözött a betegcsoport egészétől. Nem találtunk korrelációt a fovea vastagsága és a célérték feletti $\mathrm{HbA}_{1 \mathrm{c}}$-érték között a diabetes ismert tartama szerinti értékelés során sem. $\mathrm{Az}$ említett 62 beteg $\left(\mathrm{HbA}_{1 \mathrm{c}}>8,0 \%\right)$ maculavolumen-értékei (jobb szem: 7,62 $\pm 0,61 \mathrm{~mm}^{3}$, bal szem: 7,68 $\pm 0,8 \mathrm{~mm}^{3}$ ) sem különböztek szignifikáns mértékben sem a vizsgált 195 személy értékeitől, sem a standard értékektől.

$\mathrm{Az}$ adatbázisban szereplő kontrollértéket meghaladó, $>300 \mu \mathrm{m}$ maculavastagságot 11 beteg 19 szemén észleltünk, látásélességük azonban megtartott volt. Teljes visust tapasztaltunk e 11 beteg 14 szemén a centrális foveavastagság hasonló mértékű növekedése ellenére is.

A 195 betegből 13 esetében találtunk enyhe háttér-retinopathiát. Három beteg 6 szeme esetében a periférián megjelent preproliferatív retinopathia miatt panretinalis lézerkezelést, egy beteg egy szeme esetében a követési idő alatt kialakult proliferatív retinopathia és üvegtesti vérzés miatt üvegtesti mütétet végeztünk.

DME-t 12 betegnél véleményeztünk. Közülük 4 esetben nem-szteroid hatóanyag-tartalmú szem- cseppet alkalmaztunk tartós sikerrel, 3 beteg 3 szemén macula grid („rács”) lézerkezelést végeztünk, 5 beteg 9 szemét vascularis endothelialis növekedési faktor (VEGF) elleni gyógyszer (anti-VEGF, bevacizumab) intravitrealis adásával kezeltük. Ez utóbbi betegek közül egynél később az anti-VEGF hatástalansága miatt intravitrealis szteroid adására váltottunk, sikerrel.

A nem diabeteses eredetű szemfenéki betegségek közül meglepően magas számban, a vizsgált szemek 15\%-ában fordult elő epiretinalis membránképződés, visusromlást azonban ez csak két esetben okozott, a többi esetben mellékleletként detektáltuk. Nedves típusú maculadegeneratio képe 4 szem esetében, míg a száraz forma két beteg három szemében fordult elő.

Ez idő szerint 60 beteg esetében áll rendelkezésre legalább három vizsgálat adatsora. Közülük 3 csak orális antidiabetikus kezelésben részesült, 13 bázisinzulinnal kiegészített tablettás kezelés (BOT) alatt állt, míg napszakos inzulinkezelést folytatott 44 fő. Ez utóbbiak között az 1-es típusú diabetesszel (T1DM) kezeltek száma alacsony volt, ezért feldolgozásunkban a napi 3 vagy több inzulininjekciót adagolókat a diabetes típusától függetlenül, egységes csoportként elemeztük.

E betegek adatait külön értékelve azt találtuk, hogy az első vizsgálat alkalmával $>8,0 \%$ $\mathrm{HbA}_{1 \mathrm{c}}$-értékkel rendelkező személyek maculavolumenének átlaga magasabb, mint a $<8,0$ csoportba tartozóké, de nem haladta meg a standard kontrollként szereplő értéket. Ugyanezen felosztás szerint a betegek $\mathrm{HbA}_{1 c}$-értékkel jellemzett anyagcsere-állapota a követés során az első csoportban javult $(8,76 \pm 0,7$, a 2 . év végén $6,66 \pm 0,74$; $\mathrm{p}<0,05)$, a másodikban, érdemben nem változott $(7,67 \pm 1,48$, illetve $7,02 \pm 0,83 \%)$. A macula átlagos térfogata értékelhetően sehol sem változott. Azon betegeknél, akiknél a kezdetben is magasabb $(>8,0 \%) \mathrm{HbA}_{1 \mathrm{c}}$-értéket nem sikerült a köve-

2. táblázat. A vizsgálatba vontak és a standard kontrollként nyilvántartott fovea/macula értékek összevetése

\begin{tabular}{|c|c|c|c|}
\hline & Jobb szem & Bal szem & Standard \\
\hline Átlagos foveavastagság $(\mu \mathrm{m})$ & $268,52 \pm 25,05$ & $272,50 \pm 31,25$ & $200-300$ \\
\hline Centrális foveavastagság $(\mu \mathrm{m})$ & $201,79 \pm 49,00$ & $208,27 \pm 65,54$ & $160-250$ \\
\hline Maculatérfogat $\left(\mathrm{mm}^{3}\right)$ & $7,46 \pm 0,61$ & $7,51 \pm 0,80$ & $6,8-7,6$ \\
\hline
\end{tabular}


tés során csökkenteni, sőt esetenként még tovább is emelkedett, a maculavastagság nőtt (átlagos $\mathrm{HbA}_{1 \mathrm{c}} 8,76 \pm 0,52 \%$, majd $9,06 \pm 1,55 \%$, maculavastagság 7,53 $\pm 0,59$, illetve $7,98 \pm 0,61 \mu \mathrm{m}$ ).

\section{Megbeszélés}

A nem traumás eredetű látásvesztés leggyakoribb oka a diabeteses retinopathia (DRP). Felmérések szerint ma világszerte 93 millióra tehető a valamilyen mértékű DRP-vel szövődött esetek száma, közülük 21 millió fő esetében maculaoedema is fennáll. ${ }^{3,6,7}$

A Wisconsin Diabeteses Retinopathia Epidemiológiai Vizsgálat szerint 30 évnyi ismert diabetestartamot követően majdnem minden betegnél jelentkezik valamilyen mértékű DRP és a 65-70 éves korcsoportban a betegek 14-20\%-a vak. Diabeteses maculaoedemát (DME) >20 éve ismert 2-es típusú diabetes (T2DM) fennállásakor a betegek 29\%-ában találtak, míg T1DM esetében $>10$ éves betegségtartam esetén a gya- koriság $11-14 \%$ volt. $^{8}$ Európai adatok szerint a cukorbetegek 1,9\%-ánál ismerhető fel DRP, a DME előfordulása különböző vizsgálatokban 11,4-45,3\% között változott, az új esetek éves incidenciáját 21,9\%-nak találták. ${ }^{4,6,9}$ A magyar betegek között a szemészeti szövődmények éves incidenciája 16\%. A magyarországi vaksági statisztika szerint évente kb. 1000 ember veszti el a látását diabeteses szövődmények miatt, ami egyébként hazánkban a vakság második leggyakoribb oka a 20 és 80 év közötti népességben (20 év alatt a retinopathia prematurorom, 80 év fölött az életkor-függő maculadegeneratio a vezető ok). ${ }^{3,10}$

Az éleslátás helyén kialakuló retinakárosodás a kezelési és prognosztikai okokból önálló entitást képező maculopathia, ${ }^{6}$ amelynek a háttérben álló patogenetikai történések függvényében két fö formája különíthető el. Az ún. ischaemiás formában a terület vérellátása, perfúziója károsodik. A másik az oedemaképződéssel járó forma, amely különböző súlyosságú lehet, az egy kapillárisból származó fokális elváltozástól (3. ábra) a teljes hátsó pólust érintő diffúz, gyakran cystoid mintázatú

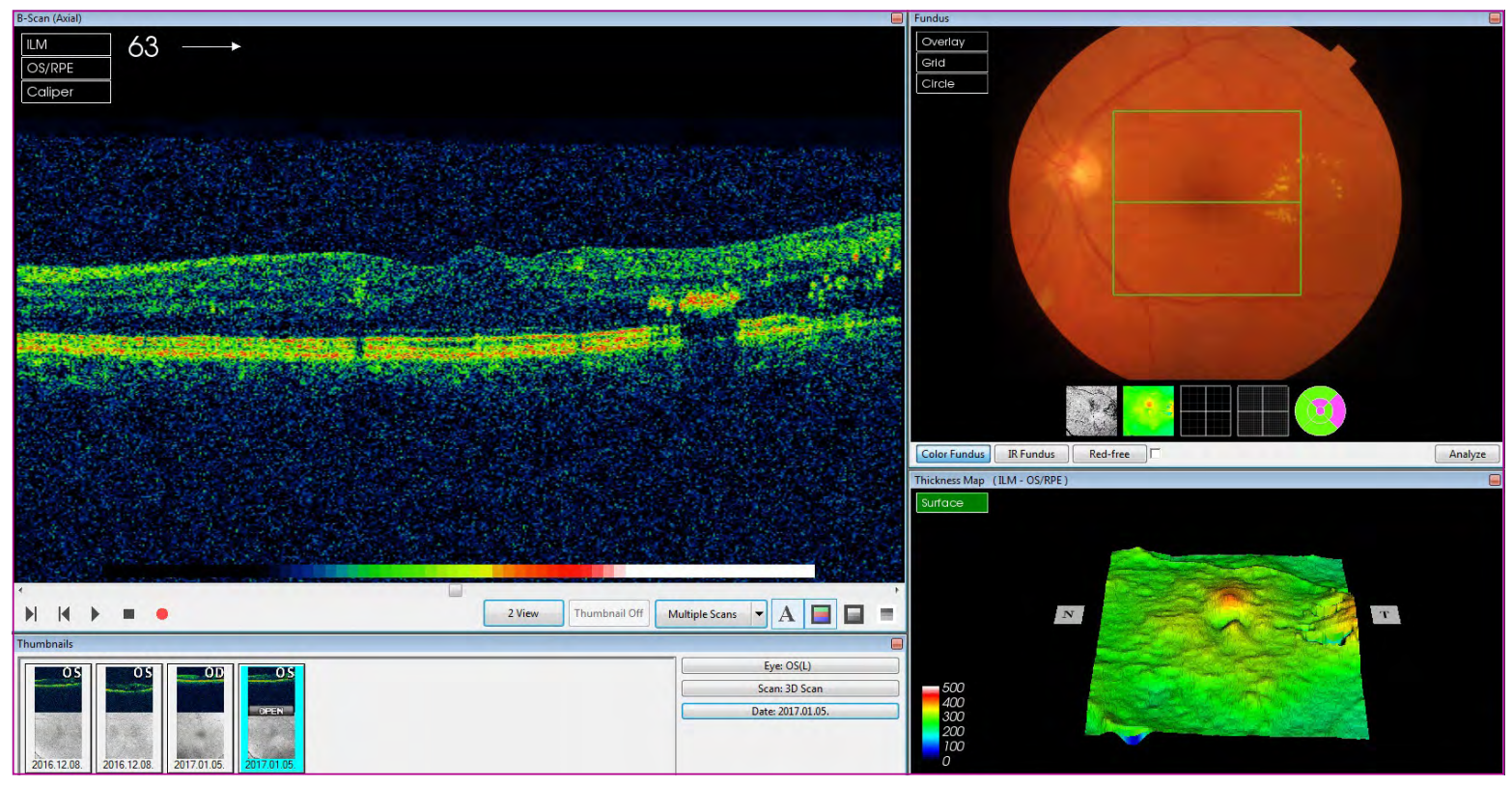

\section{3. ábra. Fokális maculaoedema OCT-és szemfenéki képe}

Az ábrán a jobb felső sarokban a szemfenéki kép látható. A zöld négyzet által határolt terület az a 6×6 mm-es négyzet, amelyröl OCT scaneket készítünk. A középső zöld vonalnak megfelelő keresztmetszeti képet látjuk a bal oldalon. Jól megfigyelhető a fovea szerkezetének megváltozása, elődomborodása, valamint az árnyékoló kemény exsudatum a foveától temporálisan. A jobb alsó képen a 6×6-os terület topografikus ábrázolása látható 
oedemáig. A DRP súlyossága és a DME megjelenése között nincs közvetlen összefüggés. ${ }^{9}$

Otani és munkatársai 1999-ben közölt, ma is használt csoportosítása szerint diabeteses maculopathiában a retina háromfajta morfológiai eltérése különböztethető meg az OCT-kép alapján: a diffúz maculaoedema, ahol a retina vastagsága meghaladja a kornak megfelelő normális értékeket, de strukturális eltérés még nem látható, a cystoid maculaoedema, ahol a retina megvastagodott állományában jól kivehető üregképződést látunk a foveolaris behúzottság eltűnésével. Harmadik eltérésként a serosus maculaleválást említik, amely az előzőek bármelyikéhez társulhat, s a pigmenthám és a neuroepithelium között felhalmozódott folyadéknak felel meg. Súlyosság szerint lehet enyhe, amikor mérsékelt a retina megvastagodása, vagy kemény exsudatumok láthatók a hátsó póluson, de messze a centrumtól; mérsékelt, amikor a megvastagodás és a kemény exsudatumok megközelítik a centrumot, de nem foglalják magukban; és súlyos. Ez utóbbi esetben a megvastagodás és a kemény exsudatunok a centrumban vannak. ${ }^{11}$

2008-ban vezették be a CSM definícióját, ${ }^{6}$ amely az észlelt elváltozás kiterjedése és az éleslátás helyétől való távolsága függvényében jelzi a maculakárosodás súlyosságát. A >500 $\mu \mathrm{m}$, azaz fél $\mathrm{mm}$ feletti eltérés általában réslámpás vizsgálattal is észlelhető, az ez alatti károsodás azonban biztonsággal csak OCT segítségével ismerhető fel. A beosztás klinikai jelentősége a kezelés megtervezésében van.

A macula legkisebb károsodása is az életminőséget rontó látásromlással járhat. A fovea eltérései képtelenné tehetik a beteget autóvezetésre, írásra-olvasásra, összességében csökkenhet az önellátó képesség. Ha azonban a laesio nem centrális elhelyezkedésű, nem feltétlenül okoz látáspanaszt. Súlyos látásvesztés elsősorban proliferatív DRP és az ebből adódó szövődmények miatt alakul ki. Ilyenkor a legjobb korrigált látásélesség 5/200 vagy rosszabb, vagyis a beteg a látásvizsgáló táblát nem látja, néhány méternyi ujjolvasása van. A maculopathiára a mérsékelt látásvesztés (angol terminussal: „legally blind”) jellemző. A károsodások nagyobb része DME, amely centrális látótérkieséssel jár.

A kezelés részletezése meghaladja munkánk terjedelmi lehetőségeit. Megemlítjük azonban, hogy a DME terápiájában az argonlézeres kezelés ,az arany standard”, amely segítségével az eresztő eret körbezárhatjuk, vagy rács mintázatú (grid) kezeléssel csökkenthetjük a terület oxigénigényét. A
DME gyulladásos eredetére utaló adatok - az üvegtesti folyadékban emelkedett citokin-, prosztaglandin-, leukotrién- és VEGF-szint -, valamint a csökkent vagy hiányzó gyulladásellenes citokinek, alátámasztják a nem-szteroid gyulladáscsökkentő cseppek és az intravitrealis szteroid (triamcinolon acetát, illetve 2011 óta a fluorokinolon acetonid) alkalmazásának jogosságát a betegség terápiájában. Alkalmaznak dexamethasont is tartós hatású, hosszú hatóanyag-leadású implantátumokként. A diabetesesre jellemző oxigénhiány következtében fellépő ér-újdonképződést gátló anti-VEGF hatású gyógyszerek (ranibizumab, aflibercept, illetve a bevacizumab) intravitrealis adása ugyancsak új terápiás lehetőség.

A gyógyszeres kezelés a centrumot érintő oedematípusokban javasolt kezelési módszer, amelyet szükség szerint ki lehet egészíteni lézerkezeléssel. Jelenleg nincs olyan vizsgálóeljárás, amellyel kimutatható lenne a DME gyulladásos eredete, az anti-VEGF hatású gyógyszerek széles körű használata és az ebből levont következtetések kimutatták azonban, hogy az esetek 30\%-a nem reagál a faktorgátlók adására, viszont gyakran javulás érhető el szteroidterápiával. A DME gyógyszeres kezelése a maculavastagság és látásélesség javulásban is jobb eredményeket mutat, mint önmagában a lézerkezelés. ${ }^{12,13,14,15}$

A jelen feldolgozásban szereplő 195 betegből 12 esetében volt kezelést indokoló maculaérintettség felismerhető. Valamennyi kórismézését csak az OCT-vizsgálat tette lehetővé. Az anyagcsere-állapot és a macula térfogata között nem találtunk egyértelmű összefüggést. Ez ellentétes más munkacsoport megfigyelésével, ahol >10 éves ismert betegségtartamú esetekben az ME jelenlététől függetlenül korrelációt találtak a macula mérete és az anyagcsere-károsodás mértéke között. ${ }^{16}$ Az eltérés magyarázatát a kisebb esetszám és a jelentős anyagcsere-károsodás hiánya magyarázhatja. Az említett munkacsoport megfigyeléseivel egyezően ${ }^{16}$ magunk is észleltük azonban a macula megvastagodását jóval a maculaoedema kialakulása előtt.

Négy betegnek - akiknél enyhe maculamegvastagodást találtunk - nem-szteroid gyulladáscsökkentő cseppet adtuk. Esetükben 1-3 hónap alatt látásjavulást és morfológiai javulást értünk el, ami azonban csak két betegnél bizonyult tartósnak. A macula fokális lézerkezelését, illetve „grid” kezelést három beteg három szeménél végeztünk, kettejüknél később ezt anti-VEGF intravitrealis adásával egészítettük ki. 
Anti-VEGF kezelést öt beteg kilenc szemén alkalmaztunk. Osztályunkon a kezelést bevacizumabbal (Avastin) végezzük, egyéni OGYIengedély megkérését követően, az OCT és a klinikai kép együttes értékelése alapján minden ellenőrzéskor külön mérlegelés szerint kap a beteg intraocularis injekciót. Az eltelt követési idő (36, 31, 28 és 24 hónap) alatt közülük négyen átlagosan 5,2 (2-12) alkalommal részesültek anti-VEGF terápiában. Egy beteg esetében azonban 3-3 intravitrealis anti-VEGF injekció adása ellenére változatlan DME folytán mindkét szembe intravitrealis triamcinolon adására kényszerültünk, ami megfelelő kezelési stratégiának bizonyult, mivel mindkét szemben a maculaszerkezet és a visus javulását eredményezte (4. ábra). Egy másik betegnél a maculaoedema miatt kezelt szemben időközben kialakult proliferatív retinopathia és üvegtesti vérzés miatt vitrectomia végzésére kényszerültünk, amit a műtét során szintén anti-VEGF (bevacizumab) adásával egészítettünk ki. A szerkezeti javulás mellett itt is visusjavulás jelentkezett (5. ábra).

A bemutatott adatok egy hosszú távúra tervezett együttműködés és betegkövetés első eredményei. Megfigyeléseink limitáló tényezőjeként említhető a feldolgozott esetszám viszonylag alacsony volta, a követésben részt vettek hasonlóan kis száma és a követési idő rövidsége. Minden törekvésünk ellenére gondozott cukorbetegeink egy része területi hovatartozás vagy személyes ismeretség folytán másik szakrendelést keres fel, vagy nem az előjegyzett időpontban jelentkezik vizsgálatra (a párhuzamosan működő szakrendelésre kerül, és adataikat nem kellő részletességgel rögzítik). A diabetológiai szakrendelésen gondozott betegeinek többsége jó vagy elfogadható anyagcsere-állapotú, ezért a kifejezetten rossz glykaemiás kontrollal rendelkezők száma alacsony. A követett betegek 8,0\%-nál kisebb vagy nagyobb $\mathrm{HbA}_{1 \mathrm{c}}$-érték szerinti szétválasztása önkényes, de ha a csoportosítást más (7,0\%-nál kisebb vagy nagyobb) értékhatár-
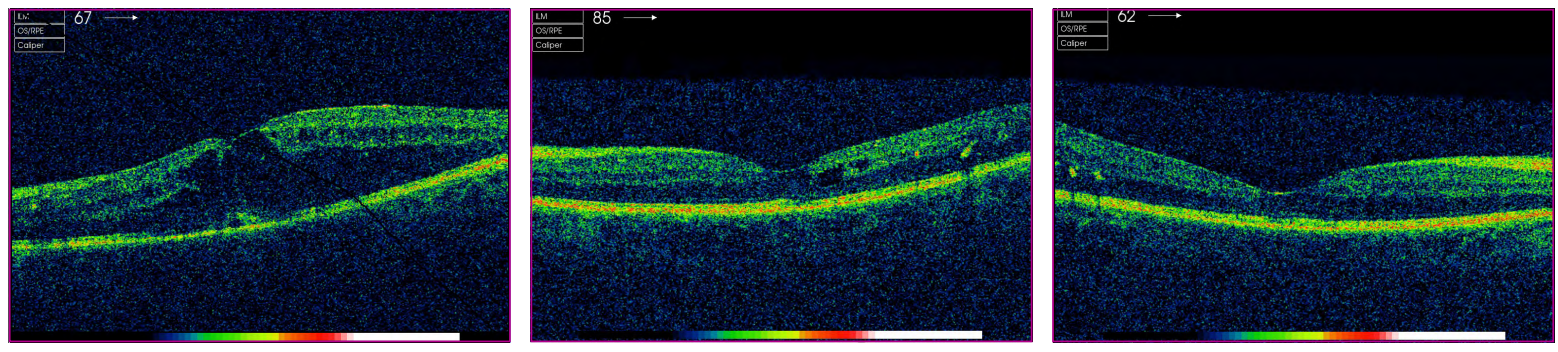

4. ábra. A foveavastagság változása anti-VEGF intravitrealis adását követően DME-ben, 3 és 6 hónap elteltével A bal oldali ábrarészlet az első vizsgálat alkalmával, a középsö a 3, a jobb szélső a 6 hónappal azt követöen rögzített állapotot szemlélteti. Az intra- és subretinalis oedema fokozatosan csökkent, kisebb a kemény exsudatumok mennyisége és mérete is, a fovea csaknem szabályos szerkezetúvé vált
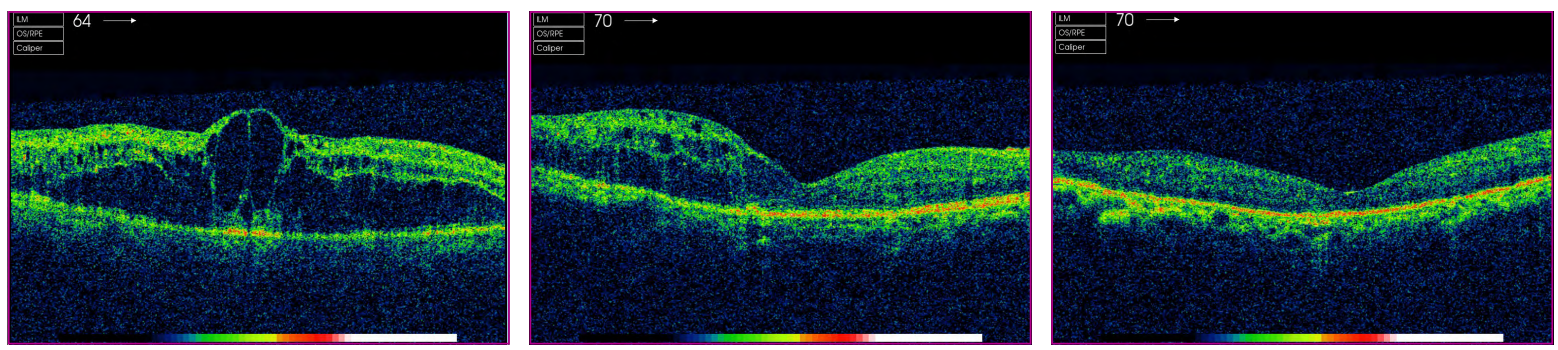

5. ábra. A maculaszerkezet alakulása az üvegtesti mütét és anti-VEGF adása elött, illetve az azt követő 3. és 15. hónapban. Az intraretinalis- és cystoid oedema jelentősen csökkent, a fovea szerkezete szabályosabbá vált 
nál végeztük, akkor sem volt a két csoport maculaadatai között eltérés kimutatható. Ezzel együtt azon kevés betegek esetében, akiknél a követési idő alatt nem sikerült a $\mathrm{HbA}_{1 \mathrm{c}}$-értéket tartósan az első észleléskor fennálló $>8,0 \%$ alá csökkenteni, a maculavastagság növekedését észleltük.

A megfigyeléseinket korlátozó tényezők ellenére adataink rávilágítanak az OCT cukorbetegek szemészeti gondozásába történő bevonásának jelentőségére. Bár a retina állapotának megítélésében nem váltja ki teljes körűen a fluorescein angiographiát, más vizsgálatokénál pontosabb információt ad a macula állapotáról. Eseteinkben az észlelt maculakárosodások többsége e nélkül nem lett volna felismerhető, s a kezelés eredményessége is csak e vizsgálattal volt biztonsággal ellenőrizhető. Az esetszám növekedésével és a követési idő meghosszabbodásával reményeink szerint lehetőség nyílik majd a maculavastagság és a glykaemiás kontroll közötti kapcsolat pontosabb felmérésére, a foveavastagság, a maculatérfogat és a későbbi látáscsökkenés összefüggésének tanulmányozására.

\section{Köszönetnyilvánítás}

A szerzők köszönetüket fejezik ki Jámbor Anita szakasszisztensnek az OCT-vizsgálatokhoz és az adatok feldolgozásához nyújtott segítségéért.

Közlésre érkezett: 2017. február 2.

Közlésre elfogadva: 2017. február 16.

\author{
A levelezésért felelös szerző: \\ Dr. Bodrogi Petra \\ Szent János Kórház és Észak-budai Egyesített \\ Intézetei, Szemészeti osztály \\ 1125 Budapest, Diós árok 1-3. \\ E-mail: bodrogipetra@gmail.com
}

Irodalom

1. Brooser G, Süveges I: A diabetes mellitus szemészeti szövődményei (in: Halmos T, Jermendy Gy /szerk. I: Diabetes mellitus - elmélet és klinikum. Medicina Könyvkiadó ZRT, Budapest, 2002, ISBN 9632427502 2) pp. 424-449.

2. Fercher AF, Drexler W, Hitzenberger CK, Lasser T: Optical coherence tomography - principles and applications. Rep Prog Phys 2003; 66: 239-303. doi:10.1088/0034-4885/66/2/204

3. Somfai GM, Somogyi A, Nemes J: A macula morfológia és a macula funkció összefüggé-sének vizsgálata cukorbetegekben optikai koherencia tomográfia segítségével. Szemészet 2004; 141: 45-54.

4. Gombos K, Bodrogi P: A szemészeti vizsgálatok jelentösége a cukorbeteggondozásban. Diabetologia Hungarica 2015; 23: 77-84.

5. Bodrogi P, Gombos K, Winkler G: Az OCT-vizsgálat szerepe a diabetes által okozott szemfenéki elváltozások megitélésében. Diabetologia Hungarica 22(Suppl. 2): 15-16.

6. Romero-Aroca P, Baget-Bernaldiz M, Pareja-Rios A, Lopez-Galvez M, Navarro-Gil R, Verges R: Diabetic macular edema pathophysiology: vasogenic vs. inflammatory. I Diabetes Res 2016; 2016: 2156273. doi:10.1155/2016/2156273

7. Kanski JJ, Bowling B: Clinical Ophthalmology. A systematic approach. 6th Edition, Elsevier, 2008.

8. Klein BE, Myers CE, Howard KP, Klein R: Serum lipids and proliferative diabetic retinopathy and macular edema in persons with long-term type 1 diabetes mellitus: the Wisconsin Epidemiologic Study of Diabetic Retinopathy. JAMA Ophthalmol 2015; 133: 503-510. doi:10.1001/jamaophthalmol.2014.5108

9. Lattanzio R, Brancato R, Pierro L, Bandello F, laccher B, Fiore T, et al:: Molecular thickness measured by optical coherence tomography (OCT) in diabetic patients. Eur J Ophthalmol 2002; 12: 482-487.

10. Németh J: A vakság okai Magyarországon. Háziorvos Továbbképzö Szemle $2011 ; 16: 5-8$.

11. Otani T, Kishi S, Maruyama Y: Patterns of diabetic macular edema with optical coherence tomography. Am J Ophthalmol 1999; 127: 688-693. doi:10.1016/50002-9394(99)00033-1

12. Schwartz SG, Scott IU, Stewart MW, Flynn HW jr: Update on corticosteroids for diabetic macular edema. Clin Ophthalmol 2016; 10: 1723-1730. doi:10.2147/OPTH.S115546

13. Holekamp NM: Overview of diabetic macular edema. Am J Manag Care 2016; 22(10 Suppl): s284-s291.

14. Dugel PU, Hillenkamp J, Sivaprasad S, Vögeler J, Mousseau MC, Wenzel A et al: Baseline visual acuity strongly predicts visual acuity gain in patients with diabetic macular edema following anti-vascular endothelial growth factor treatment across trials. Clin Ophthalmol 2016; 10: 1103-1110. doi:10.2147/OPTH.S100764

15. Park YG, Kim EY, Roh YJ: Laser-based strategies to treat diabetic macular edema: history and new promising therapies. J Ophthalmol 2014; 2014: 769213. doi:10.1155/2014/769213

16. Yeung L, Sun CC, Ku WC, Chuang LH, Chen CH, Huang BY, et al:. Associations between chronic glycosylated haemoglobin $\left(\mathrm{HbA}_{1}\right)$ level and macular volume in diabetes patients without macular oedema. Acta Ophthalmol 2010; 88: 753-758. doi:10.1111/j.1755-3768.2009.01711.x

17. Dmuschkowska DA, Krasnicki P, Mariak Z: Can optical coherence tomography replace fluorescein angiography in detection of ischemic diabetic maculopathy? Grafes Arch Clin Exp Ophthalmol 2014; 252: 731-738. doi:10.1007/s00417-013-2518-x 